\title{
R Squared
}

National Cancer Institute

\section{Source}

National Cancer Institute. R Squared. NCI Thesaurus. Code C85542.

The goodness of fit statistic for the terminal elimination phase. 